\title{
RESPONSE OF HYDROPONIC LETTUCE CULTIVARS TO DIFFERENT TREATMENTS OF NITROGEN: GROWTH AND FOLIAR NITRATE CONTENT
}

\author{
RESPUESTA DE LA LECHUGA HIDROPÓNICA A DISTINTOS \\ TRATAMIENTOS DE NITRÓGENO: CRECIMIENTO Y \\ CONTENIDO DE NITRÓGENO EN LAS HOJAS
}

\author{
Olga Lastra ${ }^{1}$; María Luisa Tapia ${ }^{2 *}$; Bruno Razeto ${ }^{2}$; Mainor Rojas ${ }^{3}$
}

\begin{abstract}
The nitrogen requirements of lettuce (Lactuca sativa L.) cultivars for obtaining plants of a high phenotypical quality and low nitrate foliar content were studied in this research. Butterhead (Divina and Prima cvs.) and loose-leaf (Grand Rapids and Brisa cvs.) lettuces were grown in a modified hydroponic floating system. Plants were subjected to four treatments differential of nitrogen and are in mg of nitrogen $\mathrm{L}^{-1}$ : solution 1: $100 \mathrm{NO}_{3}^{-}-\mathrm{N}$; solution 2:150 $\mathrm{NO}_{3}^{-}-\mathrm{N}_{\text {and }} 50 \mathrm{NH}_{4}^{+}-\mathrm{N}$; solution 3: $200 \mathrm{NO}_{3}^{-}-\mathrm{N}^{-} \mathrm{and}^{-100}$ $\mathrm{NH}_{4}^{+}-\mathrm{N}$; solution 4: $250 \mathrm{NO}_{3}^{-}-\mathrm{N}$ and $150 \mathrm{NH}_{4}^{+}-\mathrm{N}$ meanwhile as base solution was used modified Hoagland II solution. Cultivar responses to treatments were different so much in growth as foliar nitrate content. While the greatest growth was observed in 'Grand Rapids' and 'Brisa' in solution 1 with the lowest nitrogen content in which $\mathrm{NO}_{3}^{-}-\mathrm{N}$ only was supplied, the opposite was observed in 'Divina' and 'Prima' in solution 4 and where $\mathrm{NO}_{3}{ }^{-}$and $\mathrm{NH}_{4}{ }^{+}$were supplied. These results showed that the nutritional requirements cultivars are different. Moreover, greatest plant growth was observed in cultivars where the foliar nitrate content was highest. High levels of nitrate in vegetable crops have been associated with human health problem. The four cultivars in all treatments showed foliar nitrate contents below the limits established by the European Commission Legislation. This study permit to optimize the growth under such conditions.
\end{abstract}

Key words: Lactuca sativa, hydroponic lettuces cultivars, nitrogen requirements.

\section{RESUMEN}

En esta investigación se estudiaron los requerimientos de nitrógeno de los cultivos de lechuga para obtener plantas de alta calidad fenotípica y bajo contenido de nitrógeno en sus hojas. Dos tipos de lechugas (Divina and Prima cvs y Grand Rapids and Brisa cvs) fueron cultivadas en un sistema hidropónico modificado. Las plantas fueron sujetas a cuatro tratamientos diferenciales de nitrógeno y están en mg de nitrógeno $\mathrm{L}^{-1}$ : solución 1: $100 \mathrm{NO}_{3}{ }^{-}-\mathrm{N}$; solución 2:150 $\mathrm{NO}_{3}{ }^{-}-\mathrm{N}$ y $50 \mathrm{NH}_{4}{ }^{+}-\mathrm{N}$; solución 3: $200 \mathrm{NO}_{3}{ }^{-}$ $-\mathrm{N}$ y $100 \mathrm{NH}_{4}{ }^{+} \mathrm{N}$; solución 4: $250 \mathrm{NO}_{3}{ }^{-} \mathrm{N}$ y $150 \mathrm{NH}_{4}{ }^{+}$mientras que como base se usó una solución modificada de Hoagland II. Las respuestas de los cultivos a los tratamientos fueron diferentes tanto en crecimiento como en contenido de nitrato en las hojas. Mientras que se observó un mayor crecimiento en las 'Grand Rapids' y 'Brisa' en la solución 1 con el más bajo contenido de nitrógeno en el cual sólo el $\mathrm{NO}_{3}{ }^{-} \mathrm{N}$ fue aplicado, se observó lo opuesto en 'Divina' y 'Prima' en la solución 4 donde $\mathrm{NO}_{3}{ }^{-}$y $\mathrm{NH}_{4}{ }^{+}$ fueron aplicadas. Estos resultados mostraron que los requerimientos nutricionales para los cultivos son diferentes. Además, un mayor crecimiento de las plantas fue observado en cultivos donde el contenido de nitrato en las hojas fue mayor. Los altos niveles de nitrato en cultivos de verduras han sido asociados a problemas humanos. Los cuatro cultivos en todos los tratamientos mostraron contenidos de nitrato bajo los límites establecidos por la European Commission Legislation. Este estudio permite optimizar el crecimiento bajo condiciones como estas.

Palabras clave: Lactuca sativa L., cultivo hidropónico, requerimientos de N.

\footnotetext{
1 Facultad de Ciencias Químicas y Farmacéuticas, Universidad de Chile, Casilla 233, Santiago, Chile.

2 Facultad de Ciencias Agronómicas, Universidad de Chile, Casilla 1004, Santiago, Chile.

* e-mail corresponding author: mtapia@uchile.cl

3 Instituto Nacional del Café, Costa Rica.
}

Fecha de Recepción: 08 Abril 2008

Fecha de Aceptación: 03 Julio 2008 
Nitrate and ammonium are the major sources of inorganic nitrogen taken up by the roots of higher plants. The N source-nitrate, ammonium or, nitrate and ammonium-more adequate for a good plant growth depend on many factors being plant specie one of the more important. (Kirby, 1967, 1981; Kafkafi, 1990; Gamiely et al., 1991). In general, highest growth rates and plant yields are obtained by combining supply of both. (Marschner, 1985). Assays using different $\mathrm{N}$ sources in lettuce in hydroponic system were carried out by Knight and Mitchell (1983), Ikeda and Osawa (1984), Van der Boon et al., (1986, 1990), Carrasco et al., (1998).

Nitrate accumulation in plants has been related to genetic characteristics and management factors, such as nitrogen fertilization. Some vegetables crop such as beet (Beta vulgaris L.), celery (Apium graveolens), lettuce (Lactuca sativa L.), spinach (Spinacea oleraceae) and radish (Raphanus sativum L.) store nitrate in the leaves at levels, frequently exceeding $1000 \mathrm{mg} \mathrm{kg}^{-1} \mathrm{FW}$ (Carrasco, 1998). Nitrate content in plant tissue depends on the methods of $\mathrm{N}$ fertilization and the enzymatic reduction processes of nitrate in the plant (Buczek, 1985). Excessive rates of $\mathrm{N}$ fertilizers may result in elevated nitrate concentration in plant tissues Mengel (1992). This may be particularly dangerous for human health. An legally acceptable daily intake for nitrate of 3,7 $\mathrm{mg}$ nitrate $\mathrm{kg}^{-1}$ body weight day-1 was established by European Union Scientific Committee for Food in 1995. Excess of nitrate has been associated to respiratory problems -"blue baby" syndrome- and to the formation of the carcinogenic compound in human digestive track. (Taiz and Zeiger, 1998) Thus, great efforts for reducing the nitrate foliar content in lettuce have been devoted.( Knight and Mitchell, 1983; Van der Boon et al., 1986, 1990; Carrasco and Stanley, 1992; Carrasco and Stanley, 1993; Urrestarazu et al., 1998; McCallum and Willumsen, 1999; Salomez et al., 1999; Burns et al., 2004) and meet E.C. Legislation. Reinink (Reinink, 1988; Reinink and Eenink, 1988) has studied the genetic of nitrate content in this specie with the same purpose, finding a large genotypical variation.

The aim of this paper was to study the effect of different treatment of nitrogen on the agronomical behaviour and the foliar nitrate content of the four principal lettuce cultivars growing in hydroponics systems in Chile.

\section{MATERIALS AND METHODS}

\section{PLANT MATERIAL AND TREATMENTS}

Grand Rapids and Brisa (Lactuca sativa L. var. acephala) (loose leaf type) and Divina and Prima (Lactuca sativa $\mathrm{L}$ var. capitata) (butterhead type) were grown during the winter season (4 june - 12 july) in a glasshouse with mean minimum and maximum temperature $5^{\circ} \mathrm{C}$ and $18^{\circ} \mathrm{C}$, respectively. The plants were established in a modified floating hydroponic system. (Resh, 1997) Seeds were germinated in $90 \mathrm{~mL}$ polyvinylchloride pots with a hole at bottom. One plant per pot was grown in 70 $\mathrm{mL}$ of sterilized expanded perlite and vermiculite (1:1 v: v pre hydrated mix). From the emergence until $4^{\text {th }}$ to $5^{\text {th }}$ true leaves, the plant were irrigated three times per week with modified Hoagland II solution.(solution 1) (Hoagland and Arnon, 1950). Four hydroponics lettuce cultivars were subjected to four levels of nitrogen obtaining 16 treatments with four replicates each one. These treatments were initiated at the $4^{\text {th }}-5^{\text {th }}$ true leaf stage because of which each plant in polyvinylchloride pot was placed in a $1 \mathrm{~L}$ glass pot containing the respective nutrient solution (transplanting). The four different $\mathrm{N}$ level were in $\mathrm{mg} \mathrm{L}^{-1}$ : solution $1(\mathrm{~S} 1): 100 \mathrm{NO}_{3}$ -N; solution 2 (S 2): $150 \mathrm{NO}_{3}{ }^{-} \mathrm{N}$ and $50 \mathrm{NH}_{4}{ }^{+}-\mathrm{N}$; solution 3 (S 3): $200 \mathrm{NO}_{3}{ }^{-}-\mathrm{N}$ and 100 as $\mathrm{NH}_{4}{ }^{+}-\mathrm{N}$; solution 4 (S 4): $250 \mathrm{NO}_{3}{ }^{-}{ }^{-} \mathrm{N}$ and $150 \mathrm{NH}_{4}{ }^{+}-\mathrm{N}$. The base solution meanwhile contained ( $\left.\mathrm{mg} \mathrm{L}^{-1}\right): 219$ potassium, 100 calcium, 54 phosphorus, 64 sulfur, 49 magnesium, 5 iron, 0,5 boron, 0,5 manganese, 0,05 zinc, 0,02 copper, 0,01 molybdenum. Conductivity, $\mathrm{pH}$, and nutrient solution uptake were measured daily. The volume of nutrient solution taken up was replaced with distilled water. From the 21 days after transplanting, the nutrient solutions were renewed weekly. A square plant spatial arrangement of $25 \mathrm{~cm}$ spacing was used, typically use in these hydroponic systems. The maturity harvest stage was reached 50 days after transplanting.

\section{CHEMICAL AND PHYSIOLOGICAL DETERMINATIONS}

Plant height, shoot fresh weight, shoot dry weight, equatorial diameter and leaf number were determined at harvest maturity stage (50 days after transplanting). At the same stage nitrate content in fully mature leaves was determined per treatment 
and replicates. While, nitrate content on blades and midribs due to a limited sample was determined in one composite sample obtained mixing homogeneously each tissue per treatment. Nitrate concentration was determined by a first-derivative spectrophotometric method (UNICAM UV 2 Spectrophotometer, Cambridge, UK) based on nitrosalicylic acid spectral signals obtained to 388 and $440 \mathrm{~nm}$ in basic solution (Lastra, 2003).

\section{STATISTICAL ANALYSIS}

A randomized complete block design with a factorial structure (4 x 4) was used. One plant was the experimental unit. Data were subjected to analysis of variance at $5 \%$ significance level after correcting discrete variables ( $N$ corrected $=\sqrt{ } N+1)$, and Duncan's Multiple Range Test was applied to parameters that showed significant differences among treatments. Also correlation coefficients were used to analyze the experimental data. All analyses were carried out using software Jandel Sigma Stat 2.0.

\section{RESULTS AND DISCUSSION}

In general, plant height in acephala cultivars was higher than in capitata. Such a response is probably related to the proper cultivar characteristics. Only 'Divina' and 'Brisa', both of them from different botanical varieties, responded significantly to $\mathrm{N}$ treatments. But, while in the former the highest plant height was obtained with solution 4, in 'Brisa' the reverse occurred. 'Grand Rapids' and 'Prima' did not show significance differences (Figure 1).

'Grand Rapids' and 'Brisa' plants, which were exposed to solution $1\left(\mathrm{NO}_{3}{ }^{-}\right.$alone supplied) reached the greatest shoot fresh weight values. In capitata cultivars the opposite behavior was observed (Figure 2). It is important to point out that 'Grand Rapids' did not show shoot fresh weight differences between solution 1, 2 and 3; a shoot fresh weight efficient production was reached with the lowest $\mathrm{N}$ nutrient solution concentration. Instead, Knight and Mitchell (1983) reported an increasing yield in passing from 210 to $420 \mathrm{mg} \mathrm{L}^{-1} \mathrm{~N}$ - supplied as $\mathrm{NO}_{3}{ }^{-}$or $\mathrm{NO}_{3}{ }^{-}$and $\mathrm{NH}_{4}{ }^{-}$- in 'Grand Rapids' and 'Salad Bowl' whereas in 'Bibb' and 'Ruby' no effect on yield was observed. 'Brisa' present a similar behaviour to 'Grand Rapids'. Borowski (1994) and, Borowski and Michalek (1994, 1995) reported that a high ratio $\mathrm{NH}_{4}{ }^{+:} \mathrm{NO}_{3}{ }^{-}$is responsible for a significant fresh weight and yield reduction in lettuce, which is only concordant with the results obtained in the acephala botanic variety in our assay. The shoot dry weight present the same tendencies that the shoot fresh weight in the different cultivars. (Figure 3 ).

Furthermore it is necessary to make note of 'Grand rapids' and 'Brisa' roots showed damage characterized by dark color when grown in $\mathrm{NO}_{3}{ }^{-}+$

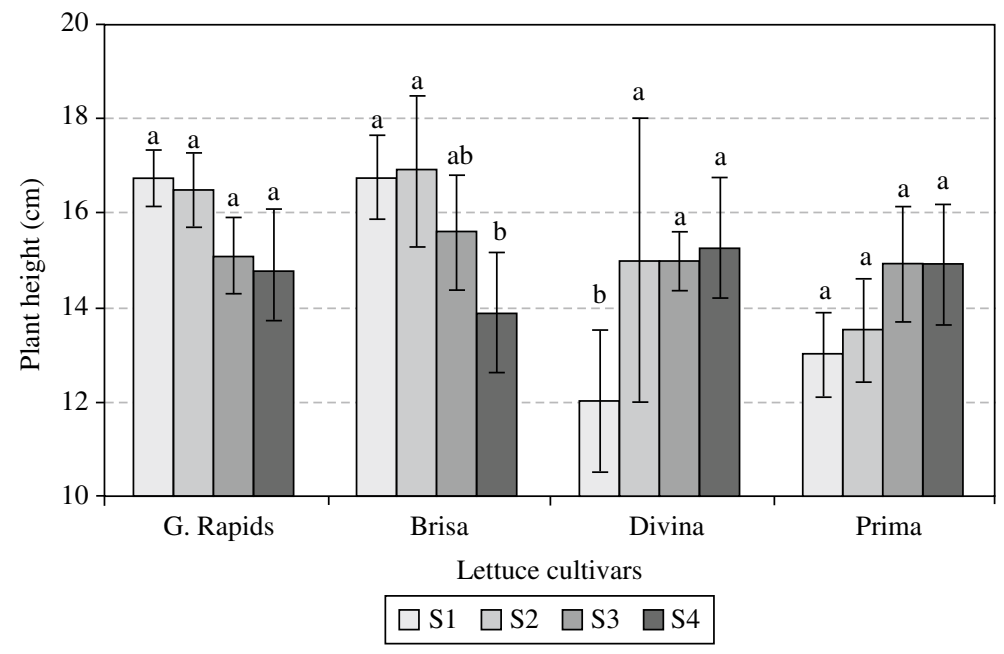

Figure 1. Mean plant height at harvest maturity stage and standard deviation $(n=4)$ for Grand Rapids, Brisa, Divina and Prima cultivars grown in four N solution concentrations: S 1, S 2, S 3, S 4 . Treatments with the same letter in the columns of each cultivar are not significantly different at $\mathrm{p} \leq 0.05$ as determined by Duncan's method. 


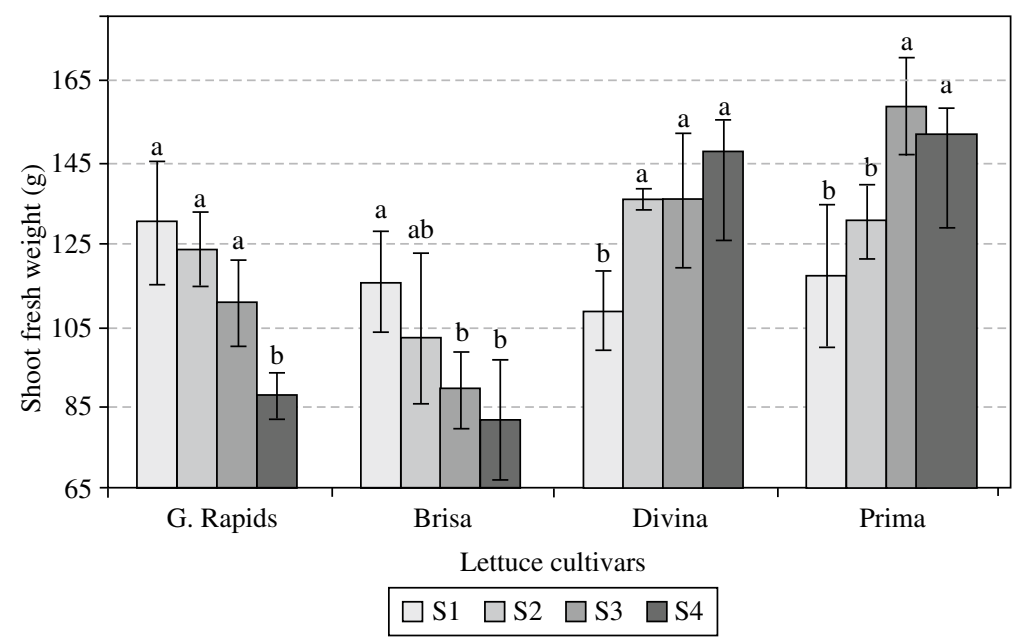

Figure 2. Mean shoot fresh weight at harvest maturity stage and standard deviation $(n=4)$ for Grand Rapids, Brisa, Divina and Prima cultivars grown in four N solution concentrations: S 1, S 2, S 3, S 4. Treatments with the same letter in the columns of each cultivar are not significantly different at $\mathrm{p} \leq 0.05$ as determined by Duncan's method.

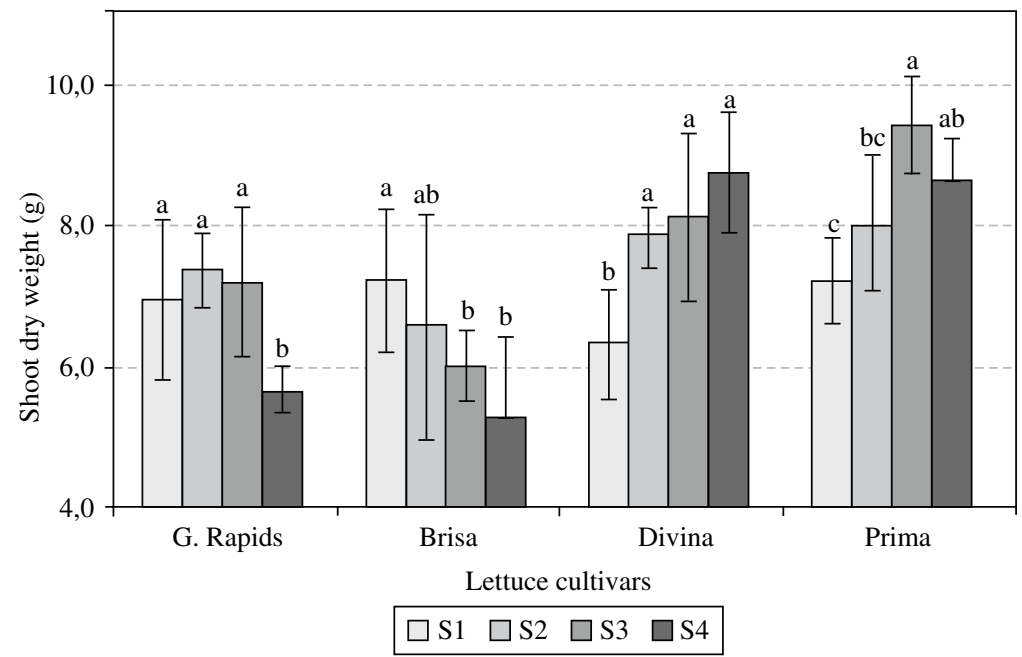

Figure 3. Mean shoot dry weight at harvest maturity stage and standard deviation $(n=4)$ for Grand Rapids, Brisa, Divina and Prima cultivars grown in four $\mathrm{N}$ solution concentrations: S 1, S 2, S 3, S 4. Treatments with the same letter in the columns of each cultivar are not significantly different at $\mathrm{p} \leq 0.05$ as determined by Duncan's method.

$\mathrm{NH}_{4}{ }^{+}$solution where rapidly $\mathrm{pH}$ decrease. This did not occur in the treatment with solution 1 , whose $\mathrm{N}$ source was only $\mathrm{NO}_{3}{ }^{-}$and the $\mathrm{pH}$ was rather steady. The ammonium assimilation in roots produces one proton per molecule taken up, which must be excreted into the external medium. (Marschner, 1995). Moritsugu et al. (1995) reported no lettuce sensitivity to high ammonium levels, but to acid $\mathrm{pH}$ produced by its absorption.
'Divina' and 'Prima' display a higher development where ammonium and nitrate are present. Ammonium is an ion quickly incorporated to root metabolism acting as derepressor of nitrate reductase. (Solomonson and Barber,1990). 'Divina' displayed a maximum in solution 3 and 4, whereas Prima displayed in solution 3 .

No significant differences in the equatorial diameter were observed among treatments in 'Grand 
Rapids' plants 50 days after transplant, in agree with Merlet (1997) who worked with the same cultivar and a nutrient solution of $345,7 \mathrm{mg} \mathrm{L}^{-1} \mathrm{~N}$. 'Brisa' showed sensitivity to high $\mathrm{N}$ concentrations, since its diameter was significantly smaller $(\mathrm{p} \leq 0.05) 47$ days after transplant in plants growing in solutions 3 and 4. No significant differences were observed among treatments in 'Divina'. In 'Prima', the plants grown in solution 1 showed the smallest equatorial diameter.

The total number of leaves per plant and marketable quality leaves were cultivar dependent and did not respond to the $\mathrm{N}$ concentration of the solution. In 'Grand rapids', the number of leaves per plant was 17 to 20, values similar to those reported by Knight and Mitchell (1983), but higher than those reported by Merlet (1997).

In all cultivars and treatments, the foliar nitrate content (Table I) in whole leaves (mean \pm standard deviation: 1087,2 $\pm 458,1 \mathrm{mg} \mathrm{kg}^{-1} \mathrm{FW} \mathrm{NO}{ }^{-}$), did not exceed the maximum values established by the European Commission Legislation (2002) which has established a maximum acceptable content of $\mathrm{NO}_{3}{ }^{-}$in lettuce of $3500 \mathrm{mg} \mathrm{kg}^{-1} \mathrm{FW}$ for greenhouse lettuce harvested in summer, $4500 \mathrm{mg} \mathrm{kg}^{-1} \mathrm{FW}$ for that harvested in winter, and $2500 \mathrm{mg} \mathrm{kg}^{-1} \mathrm{FW}$ for outdoor grown lettuce. In spite of the high $\mathrm{N}$ content in some nutrient solutions, the low foliar nitrate content can be attributable to a low nitrate storage capacity in the evaluated cultivars and, probably, to the presence of ammonium in three of the four solutions evaluated (solution 2, 3 and 4) which could have decreased nitrate absorption. In the Grand Rapids cultivar, the maximum foliar nitrate content was displayed by plants growing in the lowest $\mathrm{N}$ concentration, which coincides with the observed behaviour in the parameters previously shown. In general. In the Brisa cultivar nitrate content in the leaves was not affected by the nitrogen level in the nutrient solution. In Divina and Prima cultivars, foliar nitrate content was directly associated with $\mathrm{N}$ in the solution. Again, the genetic differences between acephala and capitata botanical varieties are evident, in accordance with the results of Corré and Breimer (1979) and Carrasco et al., ( 1998). Pate (1980) and Carrasco (1998) attribute the cultivar differences to organic acid differences in the xylem sap. In this trial the plants were harvested before sunrise, hence

Table I

Nitrate content in whole leaves, blades and midribs at harvest stage (50 days after transplant)

\begin{tabular}{|c|c|c|c|c|}
\hline \multicolumn{5}{|c|}{ Nutrient solutions ( $N$ concentration in mineral solutions $\mathbf{m g ~ L ~}^{-1}$ ) } \\
\hline Cultivars & S 1(100) & S 2 (200) & S $3(300)$ & S 4 (400) \\
\hline \multicolumn{5}{|c|}{ Nitrate content in Leaves $\left(\mathrm{mg} \mathrm{kg}^{-1} \mathbf{F W}\right)^{*}$} \\
\hline $\begin{array}{l}\text { Grand Rapids } \\
\text { Brisa } \\
\text { Divina } \\
\text { Prima }\end{array}$ & $\begin{array}{r}1544.0 \mathrm{a} \\
940.0 \mathrm{a} \\
844.5 \mathrm{c} \\
719.8 \mathrm{~b}\end{array}$ & $\begin{array}{c}722.5 \mathrm{~b} \\
723.0 \mathrm{a} \\
1102.8 \mathrm{bc} \\
824.8 \mathrm{~b}\end{array}$ & $\begin{array}{l}837.3 \mathrm{~b} \\
732.5 \mathrm{a} \\
1388.8 \mathrm{ab} \\
1834.0 \mathrm{a}\end{array}$ & $\begin{array}{r}713.0 \mathrm{~b} \\
730.8 \mathrm{a} \\
1688.5 \mathrm{a} \\
2048.3 \mathrm{a}\end{array}$ \\
\hline \multicolumn{5}{|c|}{ Nitrate content in Blades (mg kg-1 DW) } \\
\hline $\begin{array}{l}\text { Grand Rapids } \\
\text { Brisa } \\
\text { Divina } \\
\text { Prima }\end{array}$ & $\begin{array}{r}22046 \\
8509 \\
7945 \\
2979\end{array}$ & $\begin{array}{r}7654 \\
6100 \\
10354 \\
6812\end{array}$ & $\begin{array}{r}9171 \\
4329 \\
17395 \\
21910\end{array}$ & $\begin{array}{r}9723 \\
5251 \\
21309 \\
28845\end{array}$ \\
\hline \multicolumn{5}{|c|}{ Nitrate content in Midribs (mg kg $\left.{ }^{-1} \mathrm{DW}\right)$} \\
\hline $\begin{array}{l}\text { Grand Rapids } \\
\text { Brisa } \\
\text { Divina } \\
\text { Prima }\end{array}$ & $\begin{array}{l}63515 \\
35768 \\
31179 \\
22884\end{array}$ & $\begin{array}{l}32836 \\
32476 \\
39790 \\
40466\end{array}$ & $\begin{array}{l}29402 \\
28836 \\
66039 \\
62620\end{array}$ & $\begin{array}{l}25653 \\
30154 \\
70844 \\
77850\end{array}$ \\
\hline
\end{tabular}

* Treatments with the same letter in the row of each cultivar are not significantly different at $\mathrm{p} \leq 0.05$ as determined by the Duncan's Method. 
they may have had lower nitrate content than at night, but greater than in the evening. In any case these results indicate much lower nitrate content than those reported by other researchers, which is probably attributable to genetic characteristics and/ or environmental conditions. Carrasco and Stanley (1993) reported foliar nitrate contents of 4826 and $3996 \mathrm{mg} \mathrm{kg}^{-1} \mathrm{FW} \mathrm{NO}{ }_{3}^{-}$during the night's first part and sunrise, respectively.

Results obtained for capitata cultivars were lower than those pointed out by McCall and Willumsen (1999), but with the same tendency. These researchers reported increasing foliar nitrate content (3347 to $5057 \mathrm{mg} \mathrm{kg}^{-1} \mathrm{FW} \mathrm{NO}_{3}^{-}$) in the lettuce cultivar 'Comanda' (capitata, butterhead type) grown in soil with increasing $\mathrm{N}$ rates (80 to $125 \mathrm{~kg} \mathrm{Ha}^{-1} \mathrm{~N}$ ).

Nitrate content in blades was lower than that in midribs (2-4 times), which seems logical because it is in the former where the photosynthetic activity and assimilation take place, while midribs carry nitrate in the xylem sap from roots. Thus, as pointed out by Maynard and Barker (1979), Klingenberg (1995), Carrasco (1998), Reinink and Eenink (1988) nitrate distribution is varied in the different tissues.

It is important to note that Prima plants grown in solution 1 (only $\mathrm{NO}_{3}{ }^{-} \mathrm{N}$ supplied) showed the lowest nitrate content for blades and midribs, which would indicate that the most $\mathrm{N}$ absorbed was assimilated by the plant. This observation is coincident with the lowest values of shoot weight reached in this treatment, which evidences that Prima is demanding in nitrogen as $\mathrm{NH}_{4}{ }^{+}+\mathrm{NO}_{3}{ }^{-}$or $\mathrm{NH}_{4}{ }^{+}$as also 'Divina'. Reinink (1988), studying genetics of nitrate content in lettuce, point out also that a large genotypical variation has been found for nitrate content in lettuce and no physiological explanation has yet been given. And so then, Escobar-Gutiérrez et al. (2002) in a screening of lettuce cultivars detected low nitrate-accumulating genotypes.

\section{CONCLUSIONS}

It is possible to conclude that 'Prima' and 'Divina', both of them of the capitata botanical variety, respond to $\mathrm{NH}_{4}{ }^{+}-\mathrm{N}+\mathrm{NO}_{3}{ }^{-}-\mathrm{N}$, high $\mathrm{N}$ concentration in the solution increasing their productivity parameters and nitrate foliar content as well, while 'Grand Rapids' and 'Brisa', both of them acephala variety, responded to $\mathrm{NO}_{3}{ }^{-}-\mathrm{N}$, the highest yields and foliar nitrate content occur with the lowest $\mathrm{N}$ concentration (only $\mathrm{NO}_{3}{ }^{-}-\mathrm{N}$ supplied). On the other hand, although the foliar nitrate contents under the experimental conditions of this trial were lower than those established by the European Commission Legislation and by several researchers as a maximum tolerable, it is necessary to attempt to reduce foliar nitrate content in lettuce by means of adequate agronomical practices or genetic improvement. According our results is important to point out that, the great differences between botanical varieties and/or cultivars, does not allow to generalize the information on lettuce.

\section{REFERENCES}

BOROWSKI, E. 1994. Response of lettuces to nitrogen forms in conditions of full and halved air humidity. Annals Universitatis Mariae Curie Sklodowska, Sectio EEE, Horticultura 2, 73-83.

BOROWSKI, E. AND MICHALEK, W. 1994. Effect of time and holding conditions on the content of same components in lettuce leaves. Part I. Changes in contents of water, nitrates and nitrites. Annals Universitatis Mariae Curie Sklodowska, Sectio EEE, Horticultura 2, 33-41.

BOROWSKI, E. AND MICHALEK, W. 1995. Response of lettuce to nitrate or ammonium nutrition at different nutrient solution temperatures. I. Plant growth and nitrogen management. Annals Universitatis Mariae Curie Sklodowska, Sectio EEE, Horticultura 3, 119-126.

BUCZEK, J. 1985. Regulation of nitrate and nitrite reductase activities in whole cucumber plants by endogenous level of nitrate supply. Acta Physiol. Plant. 7, 21-30.

BURNS, I.G., LEE, A. AND ESCOBAR-GUTIÉRREZ, A.J. 2004. Nitrate accumulation in protected lettuce. Acta Hort, 633, 271-278.

CARRASCO, G. AND STANLEY, B. 1992. Diurnal fluctuations and nitrate accumulation and reductase activity in lettuce (Lactuca sativa L.) grown using nutrient film technique. Acta Hort, 323: 51-59.

CARRASCO, G. AND STANLEY, B. 1993. Diurnal fluctuations in nitrate uptake and nitrate accumulation in lettuce (Lactuca sativa L.). Acta Hort. 339, 137-147.

CARRASCO, G. 1998. Acumulación de nitratos en hortalizas de hoja en cultivo protegido y alternativas de control. In Seminario Internacional Avances Tecnológicos en Producción Forzada y Cultivos Hidropónicos, Talca, Chile, Octubre 30, 1998; Carrasco, G., Rebolledo, G., Urrestarazu, M., Guzmán, M., Eds.; Universidad de Talca, 87-104.

CARRASCO, G.; REBOLLEDO, P. AND HUENTUPIL, J. 1998. Contenido de nitratos en lechuga cultivada en NFT y sistema raíz flotante en período invernal. In: Resúmenes IX Congreso Latinoamericano de Horticultura y XLIX Congreso Agronómico de Chile, Santiago, Chile, Nov. 30-Dec. 3, 52.

CORRÉ, W. AND BREIMER, T. 1979. Nitrate and nitrite in vegetables. PUDOC, Wageningen, The Netherlands, Council for Agricultural Sciences and Technology, 20-35. 
ESCOBAR-GUTIÉRREZ, A.J.; BURNS, I.G., LEE, A. AND REDMONDSON, R.N. 2002. Screening lettuce cultivars for low nitrate content during summer and winter production J. Hort. Sci. Biotech. 77, 232-237.

EUROPEAN UNION SCIENTIFIC FOR FOOD. 1995. Opinion on nitrate and nitrite (expressed on 22 September 1995), Annex 4 to document III/56/95, CS/CNTM/NO3/2OFINAL, European Commission D:G III, Brussels.

GAMIELY, S., RANDLE, W.M., MILLS, H.A. AND SMITTLE, D.A. 1991. Onion plant growth bulb quality and water uptake following ammonium and nitrate nutrition. HortScience 26, 1061-1063.

HOAGLAND, D. AND ARNON, D. 1950. The water-culture method for growing plants without soil. Circular 347. University of California, Berkeley, USA, 32 p.

IKEDA, H. AND OSAWA T. 1984. Lettuce growth as influenced by $\mathrm{n}$ source and temperature of the nutrient solution.: ISOSC Proceedings 273-284

KAFKAFI, U. 1990. Root temperature, concentration and the ratio $\mathrm{NO}_{3}^{-} / \mathrm{NH} 4+$ effect on plant development. J. Plant Nutr. 13, 1291-1306.

KIRBY, E. A. 1967. A note on the utilization of nitrate, urea and ammonium nitrogen by Chenopodium album. Z. Pflanzenernähr. Bodenkd. 117, 204-209.

KIRBY, E. A. 1981. Plant growth in relation to nitrogen supply. In Terrestrial Nitrogen Cycles, Processes, Ecosystem Strategies and Management Impacts, eds. F. E. Clarke and T- Roswall, 249-267. Ecol. Bull., Stockholm.

KLINGENBERG, C. 1995. Comportamiento de las concentraciones de nitrato y nitrito en lechuga (Lactuca sativa $\mathrm{L}$. var. crispa) bajo cinco dosis de fertilización nitrogenada y otros ensayos de cosecha y postcosecha; Facultad de Agronomía, Pontificia Universidad Católica: Santiago, Chile, Tesis Ing. Agr., 52 p.

KNIGHT, S. AND MITCHELL, C. 1983. Enhancement of lettuce yield by manipulation of light and nitrogen nutrition. J. Amer. Soc. Hort. Sci. 108: 750-754.

LASTRA, O. 2003. Derivative spectrophotometric determination of nitrate in plant tissue. JAOAC Int. 86, 1101-1105.

MARSCHNER, H. 1995. Mineral Nutrition of Higher Plants. $2^{\text {nd }}$ Ed.; Academic Press Limited: London, Great Britain, 889 p.

MAYNARD, D. AND BARKER, A. 1979. Regulation of nitrate accumulation in vegetables. Acta Hort. 93, 153-159.

MCCALL, D., AND WILLUMSEN, J. 1999. Effects of nitrogen availability and supplementary light on the nitrate content of soil-grown lettuce. J. Hort. Sci. Biotech. $74,458-463$.
MENGEL, K. 1992. Nitrogen: Agricultural productivity and environmental problems. In Nitrogen Metabolism of Plants, eds K. Mengel, D. Pilbeam, Oxford Science Publications Clarendon Press: 1-15. N Y, USA.

MERLET, A. 1997. Efecto de sombreamiento en el desarrollo, crecimiento y calidad organoléptica de lechuga (Lactuca sativa L. var. acephala) cv. Grand Rapids; Facultad de Ciencias Agrarias y Forestales, Universidad de Chile: Santiago, Chile, Tesis Ing. Agr., 75 p.

MORITSUGU, M., KAWASAKI, T. AND SUZUKI, T. 1995. Comparison of absorption rates between ammonium and nitrate nitrogen in plants. Bulletin of the Research Institute for Bioresources, Okayama University 3, 91-103.

PATE, J.S. 1980. Transport and partitioning of nitrogenous solutes. Annu. Rev. Plant Physiol. 31, 313-340.

REININK, K. 1988. Improving quality of lettuce by breeding for low nitrate content. Acta Hort. 222, 121-128.

REININK, K. AND EENINK, A.H. 1988. Genotypical differences in nitrate accumulation in shoots and roots of lettuce. Sci. Hortic. Amsterdam 37, 13-24.

RESH, H.M. 1997. Cultivos hidropónicos: Nuevas técnicas de producción. $4^{\text {a }}$ Ed. Ediciones Mundi-prensa. Madrid. 509 p.

SALOMEZ, J.; HOFMAN, G.; VAN MERIERVENNE, M.; VAN CLEEMPUT O.; BLEYAERT P. AND CALUS, A. 1999. Evaluation of the current Belgian $N$ fertilization advice system for butterhead lettuce grown under glass. International workshop on ecological aspects on ecological aspects of vegetable fertilization in integrated crop production. Acta Hort. 506, 93-98.

SOLOMONSON, L.P. AND BARBER, M.J. 1990. Assimilatory nitrate reductase: functional properties and regulation. Annu. Rev. Plant Physiol. 4, 225-253.

TAIZ, L., AND ZEIGER, E. 1998. Plant Physiology. $2^{\text {nd }}$ Ed.; Sinauer Associates, Inc., Publishers: 323-328. Sunderland, MA, USA.

URRESTARAZU, M., POSTIGO,A., SALAS, M., SÁNCHEZ, A. AND CARRASCO, G. 1998. Nitrate accumulation reduction using chloride in the nutrient solution on lettuce growing by NFT in semiarid climate conditions. J. Plant Nutr. 21, 1705-1714.

VAN DER BOON, J., STEENHUIZEN, J. 1986. Nitrate in lettuce on recirculating nutrient solution. Acta Hort. $178,67-72$.

VAN DER BOON, J., STEENHUIZEN, J. AND STEINGRÖVER, G. 1990. Growth and nitrate concentration of lettuce as affected by total nitrogen and chloride concentration, $\mathrm{NH}_{4} / \mathrm{NO}_{3}$ ratio and temperature of recirculating nutrient solution. J. Hort. Sci. 65, 309-321. 

ANDROS IMPRESORES

www. androsimpresores.cl 
